\title{
Performance and eating behaviour of crossbred goats in Mediterranean climate of Turkey
}

\author{
Nazan Koluman', Mustafa Boga², Nissim Silanikove³, Murat Gorgulu'
}

\author{
1 Cukurova University, Agricultural Faculty, Animal Science Department, Balcali, Adana, Turkey. \\ ${ }^{2}$ Nidge University, Bor Vocational School, Nidge, Turkey. \\ ${ }^{3}$ Institute of Animal Science, Agricultural Research Organization, The Volcani Center, Bet Dagan, Israel.
}

\begin{abstract}
The objective of the study was to investigate milk yield and eating behaviour of crossbred goats, German Improved Fawn $\times$ Hair crossbred (GIF) and Saanen $\times$ Hair goats (S), in subtropical eastern Mediterranean climate of Turkey during early summer season. Eight GIF and eight $\mathrm{S}$ goats were individually housed in $1.5 \times 1.5 \mathrm{~m}$ pens. Diurnal eating patterns were monitored by a system that recorded meal size and meal length. Milk yield (kg/day) was 1.77 in GIF and 2.0 in S goats, whereas milk production efficiency ( $\mathrm{kg}$ feed/kg milk) was 1.15 in GIF and 1.07 in $\mathrm{S}$ goats. The differences between GIF and $\mathrm{S}$ goats in eating behaviour parameters were significant: the $\mathrm{S}$ goats had higher meal size and meal length and longer inter-meal interval, meal time, and eating rate within in each meal, but lower number of meals in comparison with GIF goats. German Improved Fawn $\times$ Hair crossbred and Saanen $\times$ Hair goats have similar lactation performance under good nutritional condition, but their eating behaviours are quite different.
\end{abstract}

Key Words: German Fawn, goat, Saanen, milk yield

\section{Introduction}

The feed intake capacity affects milk yield. Total feed intake is the outcome of meal size, meal duration, and interval between meals, which may also affect whether digestive disorders will be developed (Abijaoude et al., 2000). The eating behaviour provides a possibility to study factors that influence animal decision of what to eat and how much to eat (Meier et al., 2012). Goats are intelligent animals and, under free grazing and browsing of natural habitats, they select a mixed diet, which provides optimization of their nutritional needs and effective utilization of the natural resources (Silanikove et al., 2000a). Gipson et al. (2007) provided an example in which eating behaviour affected total intake: feed characteristics (pelleted vs non-pelleted) increased total feed intake through the increase in meal duration at a similar rate of dry matter intake within meals. Over the last decade, an effort was made by the Turkish breeders to improve the production level of local breeds by crossbreeding them with Saanen (S) and German Improved

Received November 19, 2015 and accepted August 24, 2016.

Corresponding author: muratgorgulu1963@gmail.com

http://dx.doi.org/10.1590/S1806-92902016001200006

Copyright (C) 2016 Sociedade Brasileira de Zootecnia. This is an Open Access article distributed under the terms of the Creative Commons Attribution License (http://creativecommons.org/licenses/by/4.0/), which permits unrestricted use, distribution, and reproduction in any medium, provided the original work is properly cited.
Fawn (GIF) goats. German Improved Fawn, originating from the French Alpine goats, and Saanen have almost similar yield and lactation length (Darcan and Güney, 2002). Typical milk yield in full lactation of Alpine goats ranges between 2.03 and $2.08 \mathrm{~kg}$ /day, with $3.47-3.55 \%$ fat and $3.08 \%$ protein (Mioč et al., 2008). Saanen goats are a dairy breed, which typically produce, during full lactation, $2.63-2.76 \mathrm{~kg} /$ day milk, with $3.25-3.35 \%$ fat and $3.01-3.05 \%$ protein. However, there is no comparison between these genotypes under the same feeding and climatic conditions for performances. In addition, rather limited information on eating behaviour of goats is available (Rossi et al., 1999a,b; Gorgulu et al., 2008). The objective of the present study was to compare lactation performance and eating behaviour of GIF and S goats in subtropical climatic conditions of the eastern Mediterranean part of Turkey.

\section{Material and Methods}

The experiment was carried out from June 15, 2010 to the end of July 2010 in Adana Province in the eastern Mediterranean region of Turkey. The animals of this study were housed and maintained according to the approval of animal care and use of the Ethical Committee of Cukurova University. Climatic data were recorded in nearby climatic station. The Adana Province is characterised by high air temperature and humidity during the summer season. The average daily temperature during the experiment was 
$30.10 \pm 0.17^{\circ} \mathrm{C}$, while the highest and lowest temperatures were $42{ }^{\circ} \mathrm{C}$ and $19.0^{\circ} \mathrm{C}$, respectively. The average relative humidity was $29.50 \pm 0.20 \%$. Weekly average thermal heat index (THI) was calculated by a method defined by Mader et al. (2006). The following THI prevailed during the five weeks of the experiment: $74.42 \pm 0.34$ (week 1), 73.12 \pm 0.35 (week 2), $76.34 \pm 0.39$ (week 3), $75.75 \pm 0.41$ (week 4), and $75.07 \pm 0.40$ (week 5) and for the whole period the THI was, on average, $74.88 \pm 0.17$.

The study was composed of eight GIF does in the third lactation, at $125.00 \pm 3.50$ days postpartum, weighing $51.00 \pm 0.78 \mathrm{~kg}$, which had twin kids, and eight $\mathrm{S}$ does in the third lactation, at $148.00 \pm 7.12$ days postpartum, weighing $57.75 \pm 1.28 \mathrm{~kg}$, also with twin kids. The goats were housed individually in $1.5 \times 1.5-\mathrm{m}$ pens. Each pen had one $0.4 \times 2-\mathrm{m}$ feeder and a 15-L bucket for fresh water.

The experiment lasted five weeks. Live weight change, milk yield, and feed intake were determined weekly after a training period of one week. On the last day of each week, the goats were allowed to consume all the feed to prevent sorting effect on diet composition and nutrient intake. Animals were milked by an automatic milking machine at 07.00 and $17.00 \mathrm{~h}$ and milk samples were taken from each milking and composed according to the relative milk yields. Total solids, fat, protein, lactose, casein, and urea-N contents in milk samples were determined with Milkoscan FT 120 milk analyser (FOSS Electric, Hillerd, Denmark).

The goats were fed twice daily (8.00-09.00 $\mathrm{h}$ and 14.00-15.00 h) with a diet containing 40\% alfalfa hay and $60 \%$ concentrate composed of $4-\mathrm{mm}$ pellets (Table 1). Ad libitum intake was attained by supplying 5-10\% of feed in excess to the amount consumed in the previous day; fresh water was available all times. The chemical compositions of feed ingredients were determined according to the AOAC (1998). Neutral detergent fibre (NDF) and acid detergent fibre (ADF) were analysed according to Van Soest et al. (1991) using the ANKOM fibre analyser (ANKOM, New York, USA).

The circadian eating patterns of the goats were recorded by a system that was developed for that purpose as follows: for each recording of individual eating behaviour, the feed was positioned on scales with capacity to weigh $30 \pm 0.005 \mathrm{~kg}$. The scale was connected to a computer with serial multiplier from RS232. Based on weight changes over time, the system recorded meal size and meal length during $24 \mathrm{~h}$ with intervals of $5 \mathrm{~s}$ from a shift in balance weight. The measures above were calculated with a dedicated computer program. The system was composed of six scales and each 24-h measurement was carried out with three goats from each genotype. The eating behaviours of the goats were measured on alternative days throughout the experiment.

The eating patterns of the goats (eating rate, meal size, meal length, inter-meal interval, number of meals, and total eating duration) were determined for the two genotypes from the data obtained with the above-described recording system. In addition, the meal criterion was calculated. The meal criterion, which is the longest interval accepted as part of a meal, was calculated as the interval between visits to the feeders according to procedures described earlier (Tolkamp et al., 1998; Tolkamp and Kyriazakis, 1999; Yeates et al., 2001). We applied the three-population model to calculate meal criterion by nonlinear curve fitting of the pooled and log-transformed interval lengths (expressed in seconds) against feeding events (Yeates et al., 2001).

The study was carried out in a completely randomised design. The weight changes and eating behaviour parameters were analysed by the one-way ANOVA and the weekly recorded data (feed intake, milk yield, milk production efficiency, and milk composition) were analysed by GLM with repeated measure analysis in SPSS package (Statistical Package for the Social Sciences, version 15). Week and week $\times$ genotype interaction were not significant for the evaluated data in repeated measure analyses. Differences were considered significant at $\mathrm{P} \leq 0.05$.

Table 1 - Composition ( $\% \mathrm{DM})$ of total mixed ration used in the study

\begin{tabular}{|c|c|}
\hline & $\%$ \\
\hline \multicolumn{2}{|l|}{ Ingredient } \\
\hline Barley & 5.2 \\
\hline Corn & 14.2 \\
\hline Wheat bran & 15.0 \\
\hline CDDGS & 9.1 \\
\hline Corn bran & 6.0 \\
\hline Cottonseed meal & 2.8 \\
\hline Sunflower meal & 6.0 \\
\hline Lime & 1.1 \\
\hline Salt & 0.5 \\
\hline Vitamin-mineral premix ${ }^{1}$ & 0.1 \\
\hline Alfalfa hay & 40.0 \\
\hline \multicolumn{2}{|l|}{ Chemical composition } \\
\hline Dry matter $(\%)$ & 89.9 \\
\hline Ash (\%) & 6.8 \\
\hline Ether extract $(\%)$ & 2.4 \\
\hline Crude protein $(\%)$ & 14.8 \\
\hline Acid detergent fibre $(\%)$ & 23.0 \\
\hline Neutral detergent fibre $(\%)$ & 38.0 \\
\hline Crude fibre (\%) & 16.2 \\
\hline
\end{tabular}




\section{Results and Discussion}

As detailed in the material and methods, the average THI in the present experiment was $74.88 \pm 0.17$. McDowell and Woodward (1982) suggested that THI is a good indicator of stressful thermal climatic conditions. In general, THI values of 70 or less are considered comfortable, 75-78 stressful, and values higher than 78 are distressful because animals are unable to maintain thermoregulatory mechanisms or normal body temperature (Silanikove, 2000b). Goats are better adapted to heat stress than cows and sheep (Silanikove, 2000a,b). Silanikove (2000b) and AvendanoReyes et al., (2006) reported that the homoeothermic ability of dairy goats starts to be compromised when the THI exceeds 80. Silanikove and Koluman (2015) reported that milk yield of goats is not compromised at $\mathrm{THI}<80$. It may be concluded that the present experiment was carried out under mild heat stress.

The two breeds did not differ in feed intake, milk yield, milk production efficiency, and weight changes. However, protein and casein contents in milk was lower in $\mathrm{S}$ than in the GIF goats $(\mathrm{P}<0.05)$ (Table 2). Milk yield in goats depends on genotypes, parity, kidding season, stage of lactation, and nutritional conditions. Previous comparisons between $\mathrm{S}$ and German Fawn or Alpine goats were inconsistent. In some studies, milk yield of $\mathrm{S}$ was higher than in German Fawn (Norris et al., 2011; Mioč et al., 2008), whereas in others, milk yield was lower in $\mathrm{S}$ than in German Fawn crossbreds or Alpine goats (Pambu et al., 2011; Silva et al., 2013); and in some, no differences in milk yield were found between the above-mentioned genotypes, or GIF goats (Darcan and Güney, 2002). Milk yield of goats in the present study was measured while they were in mid-lactation. Milk yields were in the typically recorded range in these breeds. The

Table 2 - Performance and milk characteristics of experimental goats $(\mathrm{X} \pm \mathrm{SX})$

\begin{tabular}{lccc}
\hline Trait & $\begin{array}{c}\text { German Improved } \\
\text { Fawn goats }\end{array}$ & $\begin{array}{c}\text { Saanen } \\
\text { goats }\end{array}$ & $\mathrm{P}<$ \\
\hline Feed intake (FI, kg/day) & $1.93 \pm 0.69$ & $2.05 \pm 0.44$ & 0.18 \\
Milk yield (MY, kg/day) & $1.77 \pm 0.18$ & $2.00 \pm 0.16$ & 0.33 \\
Milk production efficiency (FI/MY) & $1.15 \pm 0.81$ & $1.07 \pm 0.81$ & 0.51 \\
Weight change (g/day) & $53.6 \pm 6.4$ & $39.4 \pm 17.0$ & 0.45 \\
Milk characteristics & & & \\
Total solids (\%) & $12.52 \pm 0.24$ & $12.08 \pm 0.10$ & 0.12 \\
Solids nonfat (\%) & $8.40 \pm 0.08$ & $8.21 \pm 0.05$ & 0.09 \\
Fat (\%) & $3.94 \pm 0.17$ & $3.71 \pm 0.11$ & 0.28 \\
Protein (\%) & $3.44 \pm 0.07$ & $3.23 \pm 0.03$ & 0.02 \\
Lactose (\%) & $4.26 \pm 0.04$ & $4.30 \pm 0.03$ & 0.46 \\
Casein (\%) & $2.65 \pm 0.05$ & $2.51 \pm 0.03$ & 0.04 \\
Urea-N (mg/dL) & $42.66 \pm 0.58$ & $42.95 \pm 1.44$ & 0.85 \\
\hline X & & & \\
\hline
\end{tabular}

$\mathrm{X}$ - mean; SX - standard error. similar milk yield in the two breeds found in the present experiment may be partially related to the fact that GIF goats had 23 days longer lactation period than S goats. It is well known that milk yield can decrease by $15-20 \%$ after peak of milk yield in goats.

The following reasoning may explain the differences in protein content in milk between breeds: milk yield and milk protein content usually decrease as lactation progresses. High milk production may be associated with lower milk protein concentration (Zygoyiannis, 1988; Norris et al., 2011). Furthermore, Norris et al. (2011) reported that the protein content in Alpine goats was higher than in S, which is consistent with the present results.

Eating behaviour parameters significantly differed in the two genotypes in most parameters $(\mathrm{P}<0.01)$, except for total feed intake $(\mathrm{P}>0.05)$ and total activity (bouts) $(\mathrm{P}>0.05)$ (Table 3$)$. The $\mathrm{S}$ goats had higher meal criterion, meal size, meal length, inter-meal interval, total meal time, eating rate, and total activity than GIF goats. In similar studies, the following differences between GIF and S goats were found (Gorgulu et al., 2008 vs. Gorgulu et al., 2011): meal criterion, 12.88 vs $13.19 \mathrm{~min}$; number of meals, 13.25 vs. 10.75 ; meal size, 203.42 vs $161.19 \mathrm{~g} / \mathrm{meal}$; meal length, 33.08 vs 25.41 $\mathrm{min} / \mathrm{meal}$; inter-meal intervals, $76.91 \mathrm{vs} 89.04 \mathrm{~min}$; total meal time, 434.74 vs $269.56 \mathrm{~min}$; and eating rate, 10.01 and $9.05 \mathrm{~g} / \mathrm{min}$. The quantitative differences in eating behaviour parameters between the above-mentioned results and the ones of the present study are not surprising, as the goats used in those studies were in different physiological stage and the genotypes used were somewhat different. However, qualitatively, both studies showed that marked genotyperelated differences in the eating behaviour at similar stage of lactation are possible. In the present experiment, both breeds had similar total feed intake despite dissimilar eating

Table 3 - Meal characteristics and feeding behavior of experimental goats

\begin{tabular}{lcccc}
\hline & $\begin{array}{c}\text { German Improved } \\
\text { Fawn goats }\end{array}$ & $\begin{array}{c}\text { Saanen } \\
\text { goats }\end{array}$ & SEM & P $<$ \\
\hline Meal criterion $^{1}$ (min) & 13.02 & 21.11 & - & - \\
Number of meals & 14.97 & 9.88 & 0.38 & 0.01 \\
Meal size (g/meal) & 112.72 & 186.31 & 0.01 & 0.01 \\
Meal length (min) & 12.43 & 23.34 & 0.93 & 0.01 \\
Intermeal interval (min) & 66.17 & 88.45 & 4.00 & 0.01 \\
Total meals time (min) & 178.92 & 219.97 & 8.99 & 0.01 \\
Eating rate within & 10.01 & 9.05 & 0.70 & 0.17 \\
a meal (g/min) & & & & \\
Feed intake (kg/day) & 1.62 & 1.70 & 0.06 & 0.31 \\
Total feeding activity (n/day) & 19.75 & 21.51 & 0.66 & 0.06 \\
Total feeding activity (n/meal) & 3.06 & 5.22 & 0.15 & 0.00 \\
\hline
\end{tabular}

SEM - standard error of the mean.

${ }^{1}$ Determined as all feeding activities of goats in the same genotype. 
behaviour. The lower number of meals of the $\mathrm{S}$ goats was compensated for by higher meal size, meal length, intermeal interval, and eating rate in comparison with the GIF goats. Consequently, despite different eating behaviour, both genotypes had similar feed intake. Fukasawa et al. (2005) reported that genetic differences among breeds may influence intake as well as the eating behaviour of animals. Variations in eating activity observed in goat breeds may result from differences in body size and oral morphology (Provenza et al. 2003). In the present study, the genotypes had almost similar lactation stages, but the $\mathrm{S}$ goats had higher body weight than GIF. In support, Van Soest (1994) suggested that animal breeds with smaller body size may be more selective in their eating behaviour, whereas breeds with large body size may increase gastrointestinal retention time and digestive capacity. Furthermore, Caumul and Polly (2005) reported that body size may cause a variation of about $10 \%$ in skulls, $7 \%$ in mandibles, and $15 \%$ in molars among breeds. Thus, the differences in the proportions of eating behaviour may be explained by body size differences of the genotypes.

In the present experiment, marked differences in feeding activity between $\mathrm{S}$ and GIF goats when fed TMR containing $60 \%$ concentrate were not reflected in total feed intake and milk yield. Severe heat stress and poor nutrition affect negatively feed intake (Silanikove, 1992, 2000a). Thus, under harsher environmental conditions or with poorer feed quality, or under combination of both, the diverse eating behaviour of the different goat genotypes may provide advantage to the GIF breed.

\section{Conclusions}

German Improved Fawn goats have different eating behaviour in comparison with Saanen $\times$ Hair goats, which might be advantageous in animals exposed to severe heat stress and poor nutritional condition. However, these differences in eating behaviour are not reflected in feed intake and milk yields under good nutrition and mild heat stress condition.

\section{Acknowledgments}

This study was supported by Scientific Research Fund of Cukurova University, project number ZF2008/BAP18.

\section{References}

Abijaoude, J. A.; Morand-Fehr, P.; Tessier, J.; Schmidely, Ph. and Sauvant, D. 2000. Diet effect on the daily feeding behaviour, frequency and characteristics of meals in dairy goats. Livestock Production Science 64:29-37.
AOAC - Association of Official Analytical Chemistry. 1998. Official methods of analysis. 16th ed., 4th rev. Washington, D.C.

Avendano-Reyes, L.; Alvarez-Valenzuela, F. D.; Correa-Clderon, A.; Saucedo-Quintero, J. S.; Robinson, P. H. and Fadel, J. G. 2006. Effect cooling Holstein cows during the dry period on postpartum performance under heat stress conditions. Livestock Science 105:198-206.

Caumul, R. and Polly, P. D. 2005. Phylogenetic and environmental components of morphological variation: skull, mandible, and molar shape in marmots (Marmota, Rodentia). Evolution 59:2460-2472.

Darcan, N. and Güney, O. 2002. Comparative study on the performance of crossbred goats under Cukurova subtropical climate. Journal of Applied Animal Research 22:61-64.

Fukasawa, M.; Tsukada, H. and Kosako, T. 2005. Selective feeding behaviour of calves is affected by basal diet. Animal Science Journal 76:171-177.

Gipson, T. A.; Goetsch, A. L.; Detweiler, G. and Sahlu, T. 2007. Effects of feeding method, diet nutritive value and physical form and genotype on feed intake, feeding behavior and growth performance by meat goats. Small Ruminant Research 71:170-178.

Gorgulu, M.; Boga, M.; Sahin, A.; Serbester, U.; Kutlu, H. R. and Sahinler, S. 2008. Diet selection and eating behaviour of lactating goats subjected to time restricted feeding in choice and single feeding system. Small Ruminant Reserach 78:41-47.

Gorgulu, M.; Boga, M.; Sahinler, S.; Kilic, U. and Darcan, N. 2011. Meal criterion and feeding behavior in sheep and goats. Option Mediterraneennes 99:31-34.

Mader, T. L.; Davis, M. S. and Brown-Brandl, T. 2006. Environmental factors influencing heat stress in feedlot cattle. Journal of Animal Science 84:712-719.

McDowell, R. E. and Woodward, A. 1982. Concepts in animal adaptation. Comparative suitability of goats, sheep and cattle two tropical environments. p.384-393. In: Proceedings 3rd Int. Conf. on Goat Production and Disease, Tucson.

Meier, J. S.; Kreuzer, S. and Marquardt, M. 2012. Design and methodology of choice feeding experiments with ruminant livestock. Applied Animal Behaviour Science 140:105-120.

Mioč, B.; Prpić, Z.; Vnučec, I.; Barać, Z.; Sušić, V.; Samaržija, V. and Pavić, V. 2008. Factors affecting goat milk yield and composition. Mljekarstvo 58:305-313.

Norris, D.; Ngambi, J.; Benyi, W. K. and Mbajiorgu, C. A. 2011. Milk production of three exotic dairy goat genotypes in Limpopo province, South Africa. Asian Journal of Animal and Veterinary Advance 6:274-281.

Pambu, R. G.; Webb, E. C. and Mohale, L. 2011. Differences in milk yield and composition of different goat breeds rose in the same environment in South Africa. Agricultural Journal 6:237-242.

Provenza, F. D.; Villalba, J. J.; Dziba, L. E.; Atwood, S. B. and Banner, R. E. 2003. Linking herbivore experience, varied diets, and plant biochemical diversity. Small Ruminant Research 49:257-274.

Rossi, R.; Del Prete, E. and Scharrer, E. 1999a. Effect of the H1-histamine receptor agonist betahistine on drinking and eating behaviour in pygmy goats. Physiology and Behaviour 66:517-521.

Rossi, R.; Del Prete, E.; Rokitzky, J. and Scharrer, E. 1999b. Circadian drinking during ad libitum and restricted feeding in pygmy goats. Applied Animal Behaviour Science 61:253-261.

Silanikove, N. 1992. Effects of water scarcity and hot environment on appetite and digestion in ruminants: A review. Livestock Production Science 30:175-193.

Silanikove, N. 2000a. The physiological basis of adaptation in goats to harsh environments. Small Ruminant Research 35:181-193.

Silanikove, N. 2000b. Effects of heat stress on the welfare of extensively managed domestic ruminants: A Review. Livestock Production Science 67:1-18. 
Silanikove, N. and Koluman, N. 2015. Impact of climate change on the dairy industry in temperate zones: Predications on the overall negative impact and on the positive role of dairy goats in adaptation to earth warming. Small Ruminant Research 123:27-34.

Silva, F. G.; Brito, L. F.; Torres, R. A.; Ribeiro Júnior, J. I.; Oliveira, H. R.; Caetano, G. C. and Rodrigues, M. T. 2013. Factors that influence the test day milk yield and composition. Genetics and Molecular Research 12:1522-1532.

Tolkamp, B. J. and Kyriazakis, I. 1999. To split behaviour into bouts, logtransform the intervals. Animal Behaviour 57:807-817.

Tolkamp, B. J.; Allcroft, D. J.; Austin, E. J.; Nielsen, B. L. and Kyriazakis, I. 1998. Satiety splits feeding behaviour into bouts. Journal of Theoretical Biology 194:235-250.
Van Soest, P. J. 1994. Nutritional ecology of ruminants. 2nd ed. Comstock Publishing, Ithaca.

Van Soest, P. J.; Robertson, J. B. and Lewis, B. A. 1991. Methods for dietary fiber, neutral detergent fiber, and nonstarch polysaccharides in relation to animal nutrition. Journal of Dairy Science 74:3583-3597.

Yeates, M. P.; Tolkamp, B. J.; Allcroft, D. J. and Kyriazakis, I. 2001. The use of mixed distribution models to determine bout criteria for the analysis of animal behaviour. Journal of Theoretical Biology 213:413-425.

Zygoyiannis, D. 1988. Performance of indigenous goats (Capra prisca) in Greece as affected by season of kidding. World Review of Animal Production 24:31-36. 